Int. J. Dev. Biol. 60: 237-243 (2016)

doi: $10.1387 / \mathrm{ijdb} .160125 \mathrm{bb}$

\title{
Escherichia coli-based cell-free extract development for protein-based cancer therapeutic production
}

\author{
AMIN S.M. SALEHI, CONNER C. EARL, CHRISTINA MUHLESTEIN and BRADLEY C. BUNDY* \\ Department of Chemical Engineering, Brigham Young University, Provo, UT, USA
}

\begin{abstract}
Cell-free protein synthesis has been around for decades but it has never been close to becoming a robust tool for the production of biotherapeutic agents. In this review, we focus on how Escherichia coli-based cell-free protein synthesis can be modified in various ways to produce challenging, complex anticancer biotherapeutics. Here we report progress in extract preparation and its relation to cell-free cancer research. The future prospects of cell-free technology and its potential in various areas of cancer therapeutics production are also highlighted.
\end{abstract}

KEY WORDS: cell-free protein synthesis, cell extract, cancer research, anticancer biotherapeutics

\section{Introduction}

From 1991 to 2012 the cancer death rate dropped by 23 percent constituting nearly 1.7 million lives saved (Siegel etal., 2015). Much of this success could be contributed to the advances in targeted therapies such as Monoclonal antibody therapeutics (SanchezGarcia et al., 2016, Sommerfeld and Strube, 2005) and anticancer peptides (Boohaker et al., 2012, Tyagi et al., 2015). Still, cancer remains the second leading cause of death in the United States and is projected to overtake heart disease in the next few years (Group, 2013) with a projected 1,685,210 new cancer cases and 595,690 deaths in 2016 (Siegel et al., 2015).

The development of targeted oncological therapies in the field of protein biologics has revolutionized our ability to treat cancer. To date, all FDA-approved anticancer protein biologics have been produced in vivo (Sanchez-Garcia et al., 2016) where 69\% of those have been produced recombinantly in E. coli (SanchezGarcia et al., 2016). As successful as in vivo production has been and continues to be, there are still many drawbacks to the closed, transport-limited in vivo environment including 1) inability to produce cytotoxic proteins at high yields, 2) transport inhibition of non-natural components, 3) a walled in environment that complicates direct in situ monitoring, control, and dynamic optimization of required reagents (e.g cofactors, redox, translation elements), and 4) a crowded environment that can inhibit the correct folding of complex proteins (Smith et al., 2014c, Swartz, 2006, Swartz, 2012). The open, non-living environment provided by cell-free technology overcomes these limitations allowing the production of cytotoxic proteins (Salehi et al., 2016, Smith et al., 2012), unnatural amino acid (UAA) incorporation (Smith et al., 2014c, Zimmerman et al., 2014), and the rapid synthesis of personalized medicines (Kanter et al., 2007).

In this review, we will discuss the promise of $E$. coli-based cell-free extract development for protein-based cancer therapeutic production. We will discuss the advances that have allowed cell-free protein synthesis (CFPS) to become the exponentially expanding field that it is (Smith et al., 2014c). CFPS advances have been detailed in a number of broad-reaching reviews (Rosenblum and Cooperman, 2014, Smith et al., 2014c, Swartz, 2012); in this paper we will focus our discussion to a few particularly poignant advances in extract development as well as a few emerging and important technologies in anticancer research in which cell-free technology may be particularly impactful. We hope to review these ideas in an effort to give the reader a broader prospective of the past, present, and future of extract development and cancer therapeutic production.

\section{Cell extract for cell-free protein synthesis}

\section{Extract preparation}

Previously, robust and active cell extracts for cell-free protein synthesis (CFPS) required particular equipment that was costly and labor intensive. This inhibited entrance into the field and slowed the rate of progress. Fortunately, our lab and other researchers introduced the utilization of basic equipment commonly found in biotechnology labs such as incubator shakers and sonicators to produce active cell extract (Kwon and Jewett, 2015, Shrestha et al., 2012). This has increased participation in the field and is promoting

Abbreviations used in this paper: CFPS, cell-free protein synthesis; uAA, unnatural amino acid.

\footnotetext{
*Address correspondence to: Bradley C. Bundy. Brigham Young University, Department of Chemical Engineering, 350S Clyde Building, Provo, Utah 84602, USA. Tel: +001 801-422-2807. E-mail: bundy@byu.edu
}

Accepted: 28 April 2016. 
a widespread use of CFPS in biotechnology.

Potentially any organism could be used to produce the cell extract for CFPS and when selecting a source one should consider the biochemical nature of the protein and downstream applications (Katzen et al., 2005). However, E. coli is most commonly used because it is inexpensive, simple to ferment, rapidly produces protein, and is commercially available (Carlson et al., 2012). Also, only a few steps are required to prepare E. coli-based extract for CFPS as illustrated in Fig. 1. There are many resources, including videos, available describing protocols and methods of performing CFPS (Spirin and Swartz, 2008, Sun et al., 2013, Swartz et al., 2004). Below we highlight advances in the field.

\section{Strain selection}

The first step to prepare cell extract is to choose the right strain. Applications often define which strain should be used or should be engineered. The common strain that our lab and others use is E. coli BL21 Star TM (DE3) (Kim et al., 2006, Smith et al., 2014b). This strain is a generic strain with T7 expression system and mutation in RNaseE gene, which promotes the high mRNA stability and the rapid mRNA production necessary for high protein yields. The strain is particularly attractive as it is commercially available for all users.

There are a number of engineered strains for CFPS reported in literature which improve the protein production yield or have specific purpose (Calhoun and Swartz, 2006, Hong et al., 2013, Knapp et al., 2007). Dr. James Swartz at Stanford University has led this effort and has engineered an E. coli strain to better control the redox potential in CFPS by deleting the gene coding for glutathione reductase (Gor), and adding hemagglutinin tag to the thioredoxin reductase (TrxB) gene (Knapp et al., 2007). These two reductases complicate controlling the redox potential in favor of disulfide bond formation and their removal enabled better production of disulfide bond containing proteins. Extract from this strain has the ability to use the glucose as an energy source and requires less iodoacetamide (IAM) to inhibit reductases. This improves the economics of producing correctly folded disulfide bond containing proteins using CFPS such as secreted mammalian protein and vaccines (Knapp et al., 2007). The Swartz lab has also developed other E. coli strains with deletions to prevent the use of amino acids by metabolic pathways other than protein synthesis. Strains have been developed with nuclease deletions/ modifications to facilitate the stabilization and use of linear DNA to template cell-free protein production (Calhoun and Swartz, 2006, Michel-Reydellet et al., 2004, Michel-Reydellet et al., 2005). Additional efforts by other labs include the development of a genomically recoded organism where 321 UAG stop codons in $E$. coli MG1655 were substituted with the UAA stop codon and the release factor 1 gene was deleted (Lajoie et al., 2013). CFPS with extract produced from this strain resulted in improved production yields of proteins containing unnatural amino acids encoded by the UAG stop codon (Hong et al., 2013).

\section{Cell lysing method}

A prior bottleneck in cell extract preparation is lysing cells, due to the higher capital cost of needed equipment. Recent advances decreased the cost associated dramatically especially at laboratory scale. Here we briefly review a few lysing methods.

\section{High-pressure homogenization}

Using either a French press or impinge-style homogenizer, suspended cells are passed through several times at high pressure (about 20,000 psi) (Kim et al., 2006). The small eddies created by the high pressure shears the cells apart, exposing the inner soluble
Fig. 1. Schematic diagram of $E$. coli cell-extract preparation and cell-free protein synthesis steps with potential modifications. Briefly, the appropriate strain is chosen based on the desired application. E. coli cells are cultured and harvested in exponential phase. The cells are lysed using a homogenizer or sonicator and the lysate is clarified by centrifugation to remove the cell wall and genomic DNA. The resulting supernatant is separated as "cell extract" and used in CFPS reaction with additional essential and optional components. The procedures may not be the same for other organisms' cell-free system such as rabbit reticulocytes, wheat germ, or insect cells. Text in red describes variables to engineer depending on the applications. Abbreviations: UAAs, unnatural amino acids; IAM, iodoacetamide; GSSG, oxidized glutathione; GSH, reduced glutathione; NTPS, nucleoside triphosphates; RS, tRNA synthetase.
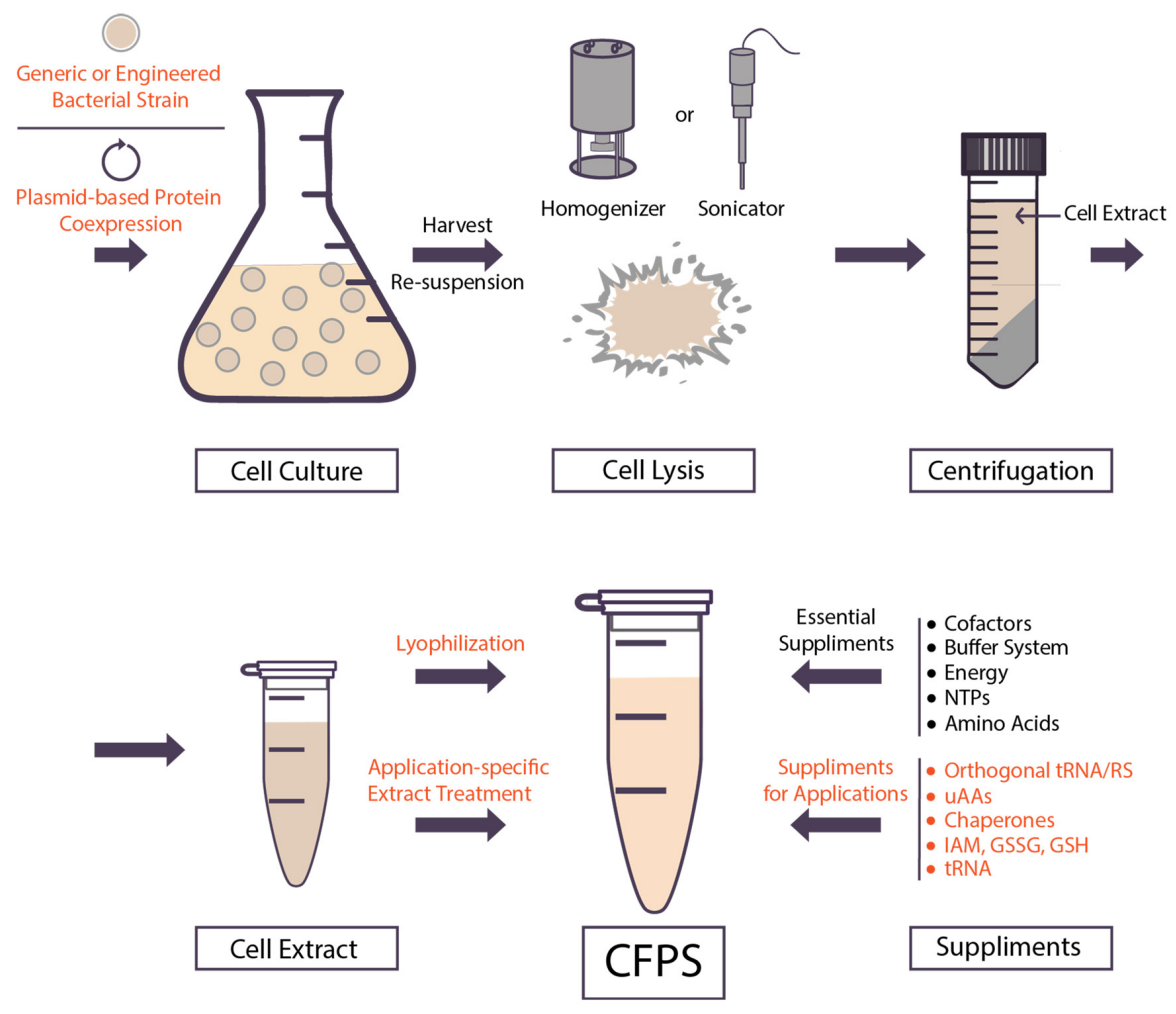
material. The homogenized lysate is then centrifuged removing the larger, less-soluble cell wall fragment, and genomic DNA. Homogenization has proved effective in cell extract preparation but requires a significant capital investment. Commercial homogenizers are available with various capacities from the milliliter to the commercial thousand liter scale and are thus ideal for large scale extract preparation.

\section{Sonication}

The sonication process requires a smaller capital cost, and the equipment is common to most biotechnology labs. By using the correct protocol, the lysis efficiency is nearly identical to high-pressure homogenization and is the recommended method for small-scale extract preparation. A small probe is placed into a sample of suspended cells, and ultrasonic sound energy is sent through the probe. This ultrasonic energy is converted into mechanical energy that vibrates the solution, causing cavitation that agitates the cells and causes them to rupture (Shrestha et al., 2012). Once again, the insoluble cell material is removed after centrifugation. In addition to the lower capital cost, the ability to perform small volume cell extract preparation, on the order of 100 $\mu \mathrm{l}$, facilitates high-throughput testing of genetically modified strains for CFPS performance (Kwon and Jewett, 2015).

\section{Other lysing method}

There are other methods available to lyse cells, but not all of them are practical for making cell extract. Methods such as freeze-thawing or lysozyme treatment can efficiently lyse cells, but the lysate did not retain protein synthesis capability (Shrestha et al., 2012). Another method developed for lysing prokaryotic cells is using bead vortex mixing. Though this method produces less protein and at greater variability of yield than homogenization and sonication, a simple table-top vortexer and glass beads are all that is needed (Shrestha et al., 2012).

\section{Cell-free scaling: Laboratory to industry}

While small scale extract production systems have benefited CFPS research, a scalable, efficient, and reproducible system is required for industrial CFPS production. For scaling up the CFPS volume, the cell extract preparation method including cell culture and lysing are not limiting steps due to decades of industrial practices developed for in vivo production of biocatalysts and biologics. However, an initial barrier to industrialize this technology was optimizing the cell-free reaction chamber due to complicated factors such as the need for oxygen for ATP regeneration, and inhibition of CFPS by byproducts such as inorganic phosphate (Caschera and Noireaux, 2015, Swartz, 2006, Swartz, 2012). Sutro Biopharma Company, a pioneer in industrializing the cell-free technology, demonstrated in 2011 the viability of a scaled up cellfree reaction from the microliter to a 100 liter scale with negligible changes in reaction kinetics and protein production yields. At the $100 \mathrm{~L}$ scale, they consistently produced high yields $(700 \mathrm{mg} / \mathrm{L})$ of granulocyte macrophage colony-stimulating factor (rhGM-CSF) (Zawada et al., 2011). This was an important advancement in industrializing the cell-free technology.

\section{Essential supplements for cell extract}

To perform CFPS and thus activate transcription/translation metabolic process, the cell extract needs a few essential supple- ments, including energy sources, amino acids, NTPs, cofactors, and a buffer system. The importance of these elements has been studied in some detail (Alexandrov and Johnston, 2014, Spirin and Swartz, 2008, Swartz et al., 2004). Here we briefly discuss energy sources as this element is one of the most expensive components in cell-free reactions.

\section{Energy resources and cost associated}

Cell-free transcription and translation requires ATP regeneration throughout the reaction, with a detailed description reported in a previous review (Swartz, 2006). Traditionally this required external enzymes, co-factors, and phosphate donor molecules (Caschera and Noireaux, 2015). Conventionally these systems use acetyl phosphate and acetate kinase, phosphoenolpyruvate and pyruvate kinase, and/or creatine phosphate and creatine kinase with each exploiting a unique metabolic pathway (Kondo et al., 1983, Shrestha et al., 2014).

During the past 15 years, engineering research focused on using alternative energy sources such as glucose and maltose has helped decrease the energy source cost by up to 1000-fold (Calhoun and Swartz, 2005, Jewett et al., 2008, Kim et al., 2011). In addition, the yield of active protein production improved by 2-fold in some cases due to reuse of inhibitory byproduct such as inorganic phosphate to generate ATP. For instance, Caschera et. al. demonstrated a cost-effective ATP regeneration system utilizing hexametaphosphate (HMP) (Caschera and Noireaux, 2015). HMP efficiently fuels protein synthesis when coupled to a carbon source (such as maltose or maltodextrin found in E. coli cell extract) and creates an ATP regeneration system that exploits endogenous enzymes from E. coli extract. Also maltodextrin (Kim et al., 2011), glutamate (Jewett et al., 2008), and glucose (Calhoun and Swartz, 2005) in combination with potassium phosphate monobasic are energy sources, which cost less than a dollar per gram. The development of less expensive and high-yielding energy sources continues to made cell-free systems a more economical alternative to produce potential biotherapeutics.

\section{Extract preparation for specific applications}

Due to less complex nature of $E$. coli compared to eukaryotic cells, cell-free expression of exogenous proteins requiring posttranslational modifications is often challenging with standard $E$. coli cell extract. Also, for some applications such as site-specific unnatural amino acid incorporation, it is necessary to add new functionalities of cell-free systems. There are many efforts to expand the capability of $E$. coli cell extract by modifying or adding exogenous elements. Here we will mention some of the main advances in extract modification.

\section{Unnatural amino acid incorporation}

Unnatural amino acid (UAA) incorporation into proteins has found its pass into many applications specifically in therapeutics. For instance, the PEGylated version of drugs has shown promising improvement in pharmacokinetic properties (Pelegri-O'Day et al., 2014). One of the key technologies to incorporate PEG molecules site-specifically into protein is using uAA incorporation (Deiters et al., 2004). In addition, uAAs can be used site specifically in antibody-drug conjugations for targeted chemotherapeutic cancer treatment (Axup et al., 2012, Zimmerman et al., 2014). There are many advances in incorporating uAAs via the cell-free system, one 
particularly promising technology was developed based on the in vivo work by the Schultz lab engineering the orthogonal tRNA/ tRNA-synthetase pairs to incorporate uAAs at amber stop codons (Wang et al., 2001). This technology was adjusted to cell-free systems to incorporate different uAAs including p-propargyloxyphenylalanine, and p-azido-L-phenylalanine, which can be selectively and covalently conjugated with copper-catalyzed and copper-free click chemistries (Bundy and Swartz, 2010, Goerke and Swartz, 2009). In earlier cell-free systems, synthetases were expressed and purified separately and then added to the cell extract. Optimization of the plasmid expressing the tRNA and tRNA synthetase has enabled sufficient expression during cell growth for extract preparation such that uAAs can be incorporated in CFPS without the need to purify and add supplemental components (Ozawa et al., 2012, Shrestha et al., 2012, Smith et al., 2013, Young et al., 2010). More details on advances in uAA incorporation using cell-free systems and its promise in therapeutic development and production can be found in the recent reviews (Des Soye et al., 2015, Quast et al., 2015).

\section{Disulfide bonds and proper folding}

Many therapeutic proteins including mammalian secreted proteins, antibodies, and fusion proteins have a complex structure with multiple disulfide bonds and are challenging to correctly fold in E. coli. In contrast, the open nature of cell-free system provides greater accessibilty to optmize the redox potential and chaperone concentration to facilitate correct protein folding. These optimization efforts include 1) using iodoacetamide (IAM) and/or strain development to inactivate/remove reductases for redox potential stabilization in cell extract (Kim and Swartz, 2004, Knapp et al., 2007);2) adding specified ratios of oxidized glutathione (GSSG) and reduced glutathione (GSH) to achieve the optimal redox poential for disulfide bond formation (Bundy and Swartz, 2011); 3) adding the disulfide bond isomerase DsbC to break incorrect disulfide bridges that form prior to proper folding (Bundy and Swartz, 2011, Knapp and Swartz, 2007). Examples of using these techniques to produce proteins with disulfide bonds include the $Q \beta$ virus-like particle (Bundy and Swartz, 2011), Candida antarctica Lipase B (Park et al., 2009), and murine granulocyte macrophage-colony stimulating factor (Knapp et al., 2007).

Additional optimization efforts have focused on facilitating protein folding using chaperones and cochaperones. Examples include expressing during cell extract preparation or directly adding the GroEL/GroES chaperones to facilitate correct folding of the industrial enzyme CalB (Park et al., 2009), Fab fragment of a catalytic antibody 6D9 (Jiang et al., 2002), and E. coli DapA protein (Shimizu et al., 2005). Also using the endoplasmic reticulum (ER) resident $\mathrm{Hsp} 70$ chaperone, $\mathrm{BiP}$, in fusion form with protein trigger factor showed improvement on soluble yield production of secreted eukaryotic proteins (Welsh et al., 2011). In another attempt, amphiphilic polysaccharide nanogels were used as artificial chaperones in CFPS to prevent aggregation of proteins and improve folding properties (Sasaki et al., 2011).

\section{Lyophilized cell extract}

The recently developed lyophilization capabililty of $E$. coli-based CFPS reagents is an important tool to expanding the applicability of CFPS technology. Lyophilized extract has been found to maintain $\sim 20 \%$ of its protein producing activity after storage at room temperature for 90 days and $\sim 30 \%$ of its activity after storage at $4^{\circ} \mathrm{C}$ for one year (Smith et al., 2014a). This facilitates facile transportation by avoiding ultralow temperature required for long-term storage of liquid form of extract. It also simplifies stockpiling large quantities for an emergency such as rapid vaccine or biotherapeutics production in response to epidemic disease or bioterrorism. Our lab demonstrated that we can efficiently produce a cytotoxic anticancer therapeutic, onconase, with a year old lyophilized cell extract (Salehi et al., 2016). Also, to create a portable CFPS platform to produce biotherapeutics and specially personalized/portable medicine and diagnostics, we reported how lyophilization can be used to sterilize and decontaminate cell extract without losing protein production capability (Smith et al., 2015). Additionally, a group of researchers recently reported a lyophilized, paper-based, in vitro system for synthetic gene network, which can expend the applications of the system into different areas including the clinic and global health (Pardee et al., 2014). They reported the use of this system as a glucose sensor and strain-specific Ebola virus sensor, which demonstrates the capability of the system to be employed in user-friendly manner in diagnostic and biosensing.

\section{CFPS for Cancer research development}

The open nature and facile manipulation of the cell-free environment allows for greater control, monitoring, and high-throughput screening techniques for improved protein evolution compared to the in vivo method (Carlson et al., 2012, Casteleijn et al., 2013, Smith et al., 2014c, Yan and Xu, 2006). While standard E. colibased cell-free systems lack the ability to perform glycosylation, the potential of using hybrid cell-free lysates and the addition of exogenous components has the promise of overcoming this limitation (Panthu et al., 2015, Zárate et al., 2010). All of these aspects combined with the high toxicity tolerance of CFPS makes this system a compelling platform for rapidly developing, screening, and producing difficult to express anticancer biotherapeutic proteins. As potential anticancer therapeutic treatments are diverse (e.g. chemotherapy (Schnipper et al., 2015), targeted therapy (Sanna et al., 2014), immunotherapy (Untch et al., 2013), photodynamic therapy (Sanna et al., 2014)), we will limit our discussion to a few emerging and important technologies in anticancer research and treatment in which cell-free technology may be particularly impactful.

\section{CFPS for personalized anticancer biotherapeutics}

One emerging application in cancer research where cell-free technology is vital is the synthesis of personalized vaccines to more quickly and efficiently treat certain types of cancers. Previous work reported that vaccine proteins for anti-cancer therapeutics could be produced rapidly in E. coli-based cell-free systems (Yang et al., 2005). In that study, a complex fusion of GM-CSF and Blymphocyte Id ScFv with different arrangements were produced successfully with CFPS (Kanter et al., 2007). Importantly cell-free reagents can be stockpiled and then scaled for reliable consistent production at the microliter, milliliter, or liter scale. Thus the major limitation becomes the time required for synthesizing the DNA that templates CFPS and custom DNAcan now be economically synthesized in as little as a day. While the implementation of customized immune therapy soon after diagnosis on a large scale requires further research and streamlining; simple, rapid and economical 
production of personalized anti-cancer therapeutics may soon be practicable using cell-free technology (Kanter et al., 2007).

\section{CFPS for challenging to express cytotoxic anticancer bio- therapeutics: Onconae case study}

Recently we published a work demonstrating the ability of CFPS to produce a hard to express anticancer biotherapeutic, onconase, which was recently in phase IIlb of clinical trials (Ardelt et al., 2008). Onconase is particularly challenging as it is a tRNase that in its active form degrades the machinery necessary to make it. The main purpose of the work was to show how CFPS can be adapted to produce a cytotoxic protein in completely active form and high yield. There have been many attempts to express and screen mutants of onconase using $E$. coli in vivo system, but most of them were limited to study of two to three mutants at the same time (Hacke et al., 2013, Notomista et al., 1999, Turcotte and Raines, 2008). The reason being aggregation of onconase and inclusion body formation. It is thus time-consuming, order of weeks, to produce the active form of the protein. By using modified CFPS, which was supplemented with tRNA throughout the reaction, onconase was produced at a yield near $2 \mathrm{mg} / \mathrm{ml}$ and solubility of more than $95 \%$. The observed anticancer activity of CFPS made onconase was 60 times more than in vivo refolded onconase, which is attributed to the inefficiency of the refolding process. Furthermore, the CFPS platform made it possible to directly test onconase anticancer activity against a cancer cell line without the need to purify the protein. Using this system, the time needed to express and test the protein was reduced to one day which is ideal for high-throughput screening. A combination of this modified cell-free method and linear template DNA, which has been studied and engineered by a number of researchers $(\mathrm{He}$ and Taussig, 2001, Woodrow et al., 2006, Yang et al., 1980), could facilitate rapid screening for a mutant onconase with increased potency against cancer cells. More information about using linear DNA templates and high-throughput CFPS can be found in recent reviews and papers (Murray and Baliga, 2013, Schinn et al., 2016, Yabuki et al., 2007).

\section{Future prospects: Additional application of CFPS in cancer research}

While many proteins of oncological value are produced recom- binantly in vivo (Sanchez-Garcia et al., 2016) cell-free technologies could contribute to improving the effectiveness and economics of these and future therapeutics. For example, the cell-free technologies of protein evolution with ribosome display can improve the solubility and activity of protein therapeutics (Buchanan et al., 2012, Carlson et al., 2012, Yan and Xu, 2006). Another important technology in oncological therapies is that of anticancer peptides. Anticancer peptides in many cases have higher target specificity, lower intrinsic toxicity, and greater ease of modification compared to full-length proteins used in chemotherapy (Barras and Widmann, 2011, Li and Cho, 2012, Tyagi et al., 2015). Peptides can also be fused to cell penetrating moieties to better target and treat cancer (Barras and Widmann, 2011). Some of these modification schemes include attaching radionuclides, hormones, vaccines, or other drugs to a nascent peptide (Thundimadathil, 2012). One great challenge in the development of clinically viable therapeutic anticancer peptides is improving delivery, minimizing non-specific toxic effects, and a greater understanding of pharmacokinetic properties (Boohaker et al., 2012).

While peptides are traditionally produced by chemical synthesis or in vivo via nucleotide sequences, these methods have significant drawbacks in time scale and cost (Lee et al., 2010). Cell-free technologies offer a compelling platform that could be explored to rapidly and more efficiently to study, screen, and produce similar peptides on an industrial level (Lee et al., 2010, Smith et al., 2014c, Swartz, 2006). For example, Lee et. al. developed a strategy for rapid cellfree expression and recovery of multiple peptide molecules (Lee et al., 2010). They optimized peptide production by developing a DNAconstruct with an enhanced sequence for improved translation efficiency, protease resistance, purification recovery, and cleavage efficiency. Continued engineering of cell-free technologies such as these demonstrates how cell-free systems could be utilized for the automated, rapid production of clinically viable pure proteins and peptides that have significant oncological value.

\section{Conclusion}

The open nature of the cell-free system makes this technology highly adaptive for new applications including cancer research. Progress during the last few decades has transformed this technology from simply a research tools to a potential industrial alternative

TABLE 1

\section{ADVANTAGES AND DISADVANTAGES OF USING CELL-FREE SYSTEMS FOR THERAPEUTICS PRODUCTION}

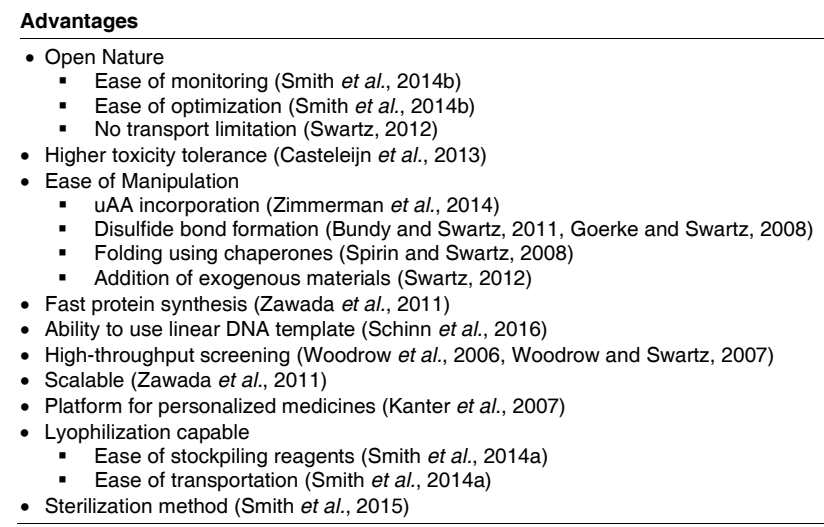

Disadvantages

- Not yet an FDA-approved Process

- Higher reagent cost compared to in vivo systems (Swartz, 2006)

- Largest industrial scale fermentation demonstrated is $100 \mathrm{~L}$ (Zawada et al., 2011)

- Limited protein synthesis life time (typically 3-12 hours in batch format) (Michel-Rydellet et al., 2004)

- Lack of cell-free specific bioreactor development reported in literatura 
for the production of many biotherapeutics. The advantages of this system, as summarized in Table 1 , have and will likely continue to be an important answer to producing some hard to express and complex anticancer biotherapeutics. Most importantly, cellfree technology could significantly reduce cancer-therapeutic development and production times and facilitate the realization of personalized cancer therapeutics.

\section{Acknowledgements}

We want to thank our funding resources for their generous contribution including National Science Foundation CBET Division CAREER Award (\#1254148) and a Brigham Young University ORCA Research Grant.

\section{References}

ALEXANDROV, K. and JOHNSTON, W.A. (2014). Cell-free Protein Synthesis: Methods and Protocols. Humana Press.

ARDELT, W., SHOGEN, K. and DARZYNKIEWICZ, Z. (2008). Onconase and amphinase, the antitumor ribonucleases from Rana pipiens oocytes. Curr Pharm Biotechnol 9: 215-225.

AXUP, J.Y., BAJJURI, K.M., RITLAND, M., HUTCHINS, B.M., KIM, C.H., KAZANE, S.A., HALDER, R., FORSYTH, J.S., SANTIDRIAN, A.F., STAFIN, K. et al., (2012). Synthesis of site-specific antibody-drug conjugates using unnatural amino acids. Proc Natl Acad Sci U S A 109: 16101-16106.

BARRAS, D. and WIDMANN, C. (2011). Promises of Apoptosis-Inducing Peptides in Cancer Therapeutics. Curr Pharm Biotechnol 12: 1153-1165.

BOOHAKER, R., LEE, M., VISHNUBHOTLA, P., PEREZ, J. and KHALED, A. (2012). The use of therapeutic peptides to target and to kill cancer cells. Curr Med Chem 19: 3794-3804.

BUCHANAN, A., FERRARO, F., RUST, S., SRIDHARAN, S., FRANKS, R., DEAN, G., MCCOURT, M., JERMUTUS, L. and MINTER, R. (2012). Improved drug-like properties of therapeutic proteins by directed evolution. Protein Eng Des Sel 25: 631-638.

BUNDY, B.C. and SWARTZ, J.R. (2010). Site-Specific Incorporation of p-Propargyloxyphenylalanine in a Cell-Free Environment for Direct Protein-Protein Click Conjugation. Bioconjug Chem 21: 255-263.

BUNDY, B.C. and SWARTZ, J.R. (2011). Efficient disulfide bond formation in virus-like particles. J Biotechnol 154: 230-239.

CALHOUN, K.A. and SWARTZ, J.R. (2005). Energizing cell-free protein synthesis with glucose metabolism. Biotechnol Bioeng 90: 606-613.

CALHOUN, K.A. and SWARTZ, J.R. (2006). Total amino acid stabilization during cell-free protein synthesis reactions. J Biotechnol 123: 193-203.

CARLSON, E.D., GAN, R., HODGMAN, C.E. and JEWETT, M.C. (2012). Cell-free protein synthesis: Applications come of age. Biotechnol Adv 30: 1185-1194.

CASCHERA, F. and NOIREAUX, V. (2015). A cost-effective polyphosphate-based metabolism fuels an all E. coli cell-free expression system. Metab Eng 27: 29-37.

CASTELEIJN, M.G., URTTI, A. and SARKHEL, S. (2013). Expression without boundaries: Cell-free protein synthesis in pharmaceutical research. Int J Pharm 440:39-47.

DEITERS, A., CROPP, T.A., SUMMERER, D., MUKHERJI, M. and SCHULTZ, P.G. (2004). Site-specific PEGylation of proteins containing unnatural amino acids. Bioorg Med Chem Lett 14: 5743-5745.

DES SOYE, B.J., PATEL, J.R., ISAACS, F.J. and JEWETT, M.C. (2015). Repurposing the translation apparatus for synthetic biology. Curr Opin Chem Biol 28: 83-90.

GOERKE, A.R. and SWARTZ, J.R. (2008). Development of cell-free protein synthesis platforms for disulfide bonded proteins. Biotechnol Bioeng 99: 351-367.

GOERKE, A.R. and SWARTZ, J.R. (2009). High-Level Cell-Free Synthesis Yields of Proteins Containing Site-Specific Non-Natural Amino Acids. Biotechnol Bioeng 102: 400-416.

GROUP, U.C.S.W. (2013). United States cancer statistics: 1999-2010 incidence and mortality web-based report. Atlanta: US Department of Health and Human Services, Centers for Disease Control and Prevention and National Cancer Institute.

HACKE, M., GRUBER, T., SCHULENBURG, C., BALBACH, J. and ARNOLD, U. (2013). Consequences of proline-to-alanine substitutions for the stability and refolding of onconase. FEBS J 280: 4454-4462.
HE, M. and TAUSSIG, M.J. (2001). Single step generation of protein arrays from DNA by cell-free expression and in situ immobilisation (PISA method). Nucleic Acids Res 29: e73-e73.

HONG, S.H., NTAI, I., HAIMOVICH, A.D., KELLEHER, N.L., ISAACS, F.J. and JEWETT, M.C. (2013). Cell-free Protein Synthesis from a Release Factor 1 Deficient Escherichia coli Activates Efficient and Multiple Site-specific Nonstandard Amino Acid Incorporation. ACS Synth Biol 3: 398-409.

JEWETT, M.C., CALHOUN, K.A., VOLOSHIN, A., WUU, J.J. and SWARTZ, J.R. (2008). An integrated cell-free metabolic platform for protein production and synthetic biology. Mol Syst Biol 4.

JIANG, X., OOKUBO, Y., FUJII, I., NAKANO, H. and YAMANE, T. (2002). Expression of Fab fragment of catalytic antibody 6D9 in an Escherichia coli in vitro coupled transcription/translation system. FEBS Lett 514: 290-294.

KANTER, G., YANG, J., VOLOSHIN, A., LEVY, S., SWARTZ, J.R. and LEVY, R. (2007). Cell-free production of ScFv fusion proteins: an efficient approach for personalized lymphoma vaccines. Blood 109: 3393-3399.

KATZEN, F., CHANG, G. and KUDLICKI, W. (2005). The past, present and future of cell-free protein synthesis. Trends Biotechnol 23: 150-156.

KIM, D.M. and SWARTZ, J.R. (2004). Efficient production of a bioactive, multiple disulfide-bonded protein using modified extracts of Escherichia coli. Biotechnol Bioeng 85: 122-129.

KIM, H.-C., KIM, T.-W. and KIM, D.-M. (2011). Prolonged production of proteins in a cell-free protein synthesis system using polymeric carbohydrates as an energy source. Process Biochem 46: 1366-1369.

KIM, T.W., KEUM, J.W., OH, I.S., CHOI, C.Y., PARK, C.G. and KIM, D.M. (2006). Simple procedures for the construction of a robust and cost-effective cell-free protein synthesis system. J Biotechnol 126: 554-561.

KNAPP, K.G., GOERKE, A.R. and SWARTZ, J.R. (2007). Cell-free synthesis of proteins that require disulfide bonds using glucose as an energy source. Biotechnol Bioeng 97: 901-908.

KNAPP, K.G. and SWARTZ, J.R. (2007). Evidence for an additional disulfide reduction pathway in Escherichia coli. J Biosci Bioeng 103: 373-376.

KONDO, H., TOMIOKA, I., NAKAJIMA, H. and IMAHORI, K. (1983). Construction of a system for the regeneration of adenosine 5'-triphosphate, which supplies energy to bioreactor. J Appl Biochem 6: 29-38.

KWON, Y.-C. and JEWETT, M.C. (2015). High-throughput preparation methods of crude extract for robust cell-free protein synthesis. Sci Rep 5: 8663.

LAJOIE, M.J., ROVNER, A.J., GOODMAN, D.B., AERNI, H.R., HAIMOVICH, A.D., KUZNETSOV, G., MERCER, J.A., WANG, H.H., CARR, P.A., MOSBERG, J.A. et al., (2013). Genomically Recoded Organisms Expand Biological Functions. Science 342: 357-360.

LEE, K.-H., KWON, Y.-C., YOO, S.J. and KIM, D.-M. (2010). Ribosomal synthesis and in situ isolation of peptide molecules in a cell-free translation system. Protein Expr Purif 71: 16-20.

LI, Z.J. and $\mathrm{CHO}, \mathrm{C} . \mathrm{H}$. (2012). Peptides as targeting probes against tumor vasculature for diagnosis and drug delivery. $J$ Transl Med 10: S1.

MICHEL-REYDELLET, N., CALHOUN, K. and SWARTZ, J. (2004). Amino acid stabilization for cell-free protein synthesis by modification of the Escherichia coli genome. Metab Eng 6: 197-203.

MICHEL-REYDELLET, N., WOODROW, K. and SWARTZ, J. (2005). Increasing PCR fragment stability and protein yields in a cell-free system with genetically modified Escherichia coli extracts. J Mol Microbiol Biotechnol 9: 26-34.

MURRAY, C.J. and BALIGA, R. (2013). Cell-free translation of peptides and proteins:from high throughput screening to clinical production. Curr Opin Chem Biol 17: 420-426.

NOTOMISTA, E., CAFARO, V., FUSIELLO, R., BRACALE, A., D'ALESSIO, G. and DI DONATO, A. (1999). Effective expression and purification of recombinant onconase, an antitumor protein. FEBS Lett 463: 211-215.

OZAWA, K., LOSCHA, K.V., KUPPAN, K.V., LOH, C.T., DIXON, N.E. and OTTING, G. (2012). High-yield cell-free protein synthesis for site-specific incorporation of unnatural amino acids at two sites. Biochem Biophys Res Commun 418: 652-656.

PANTHU, B., DÉCIMO, D., BALVAY, L. and OHLMANN, T. (2015). In vitrotranslation in a hybrid cell free lysate with exogenous cellular ribosomes. Biochem J467:387-398.

PARDEE, K., GREEN, ALEXANDERA., FERRANTE, T., CAMERON, D.E., DALEYKEYSER, A., YIN, P. and COLLINS, JAMES J. (2014). Paper-Based Synthetic Gene 
Networks. Cell 159: 940-954.

PARK, C.-G., KIM, T.-W., OH, I.-S., SONG, J.K. and KIM, D.-M. (2009). Expression of functional Candida antarctica lipase $B$ in a cell-free protein synthesis system derived from Escherichia coli. Biotechnol Prog 25: 589-593.

PELEGRI-O'DAY, E.M., LIN, E.-W. and MAYNARD, H.D. (2014). Therapeutic protein-polymer conjugates: advancing beyond PEGylation. J Am Chem Soc 136: 14323-14332.

QUAST, R.B., MRUSEK, D., HOFFMEISTER, C., SONNABEND, A. and KUBICK, S. (2015). Cotranslational incorporation of non-standard amino acids using cell-free protein synthesis. FEBS Lett 589: 1703-1712.

ROSENBLUM, G. and COOPERMAN, B.S. (2014). Engine out of the chassis: Cellfree protein synthesis and its uses. FEBS Lett 588: 261-268.

SALEHI, A.S.M., SMITH, M.T., BENNETT, A.M., WILLIAMS, J.B., PITT, W.G. and BUNDY, B.C. (2016). Cell-free protein synthesis of a cytotoxic cancer therapeutic: Onconase production and a just-add-water cell-free system. Biotechnol $J$ 11: 274-281.

SANCHEZ-GARCIA, L., MARTíN, L., MANGUES, R., FERRER-MIRALLES, N., VÁZQUEZ, E. and VILLAVERDE, A. (2016). Recombinant pharmaceuticals from microbial cells: a 2015 update. Microb Cell Fact 15: 1

SANNA, V., PALA, N. and SECHI, M. (2014). Targeted therapy using nanotechnology: focus on cancer. Int J Nanomedicine 9: 467.

SASAKI, Y., ASAYAMA, W., NIWA, T., SAWADA, S.I., UEDA, T., TAGUCHI, H. and AKIYOSHI, K. (2011). Amphiphilic Polysaccharide Nanogels as Artificial Chaperones in Cell-Free Protein Synthesis. Macromol Biosci 11: 814-820.

SCHINN, S.-M., BROADBENT, A., BRADLEY, W.T. and BUNDY, B.C. (2016). Protein synthesis directly from PCR: progress and applications of cell-free protein synthesis with linear DNA. N Biotechnology 33: 480-487.

SCHNIPPER, L.E., DAVIDSON, N.E., WOLLINS, D.S., TYNE, C., BLAYNEY, D.W., BLUM, D., DICKER, A.P., GANZ, P.A., HOVERMAN, J.R. and LANGDON, R. (2015). American Society of Clinical Oncology statement: a conceptual framework to assess the value of cancer treatment options. J Clin Oncol. 2015.61. 6706.

SHIMIZU, Y., KANAMORI, T. and UEDA, T. (2005). Protein synthesis by pure translation systems. Methods 36: 299-304.

SHRESTHA, P., HOLLAND, T.M. and BUNDY, B.C. (2012). Streamlined extract preparation for Escherichia coli-based cell-free protein synthesis by sonication or bead vortex mixing. Biotechniques 53: 12.

SHRESTHA, P., SMITH, M.T. and BUNDY, B.C. (2014). Cell-free unnatural amino acid incorporation with alternative energy systems and linear expression templates. N Biotechnology 31: 28-34

SIEGEL, R.L., MILLER, K.D. and JEMAL, A. (2016). Cancer statistics, 2016. CA Cancer J Clin 66: 7-30.

SMITH, M.T., BENNETT, A.M., HUNT, J.M. and BUNDY, B.C. (2015). Creating a completely "cell-free" system for protein synthesis. BiotechnolProg 31:1716-1719.

SMITH, M.T., BERKHEIMER, S.D., WERNER, C.J. and BUNDY, B.C. (2014a). Lyophilized Escherichia coli-based cell-free systems for robust, high-density, long-term storage. Biotechniques 56: 186-193.

SMITH, M.T., HAWES, A.K., SHRESTHA, P., RAINSDON, J.M., WU, J.C. and BUNDY, B.C. (2014b). Alternative Fermentation Conditions for Improved Escherichia colibased Cell-free Protein Synthesis for Proteins Requiring Supplemental Components for Proper Synthesis. Process Biochem.

SMITH, M.T., WILDING, K.M., HUNT, J.M., BENNETT, A.M. and BUNDY, B.C. (2014c). The emerging age of cell-free synthetic biology. FEBS letters 588: 2755-2761.

SMITH, M.T., WU, J.C., VARNER, C.T. and BUNDY, B.C. (2013). Enhanced protein stability through minimally invasive, direct, covalent, and site-specific immobilization. Biotechnol Prog 29: 247-254.

SMITH, M.T., VARNER, C.T., BUSH, D.B. and BUNDY, B.C. (2012). The incorporation of the $A 2$ protein to produce novel $Q \beta$ virus-like particles using cell-free protein synthesis. Biotechnol Prog 28: 549-555.
SOMMERFELD, S. and STRUBE, J. (2005). Challenges in biotechnology production-generic processes and process optimization for monoclonal antibodies. Chem Eng Process 44: 1123-1137.

SPIRIN, A.S. and SWARTZ, J.R. (2008). Cell-free protein synthesis: methods and protocols. John Wiley \& Sons.

SUN, Z.Z., HAYES, C.A., SHIN, J., CASCHERA, F., MURRAY, R.M. and NOIREAUX, V. (2013). Protocols for implementing an Escherichia coli based TX-TL cell-free expression system for synthetic biology. J Vis Exp. 79: 50762.

SWARTZ, J. (2006). Developing cell-free biology for industrial applications. J Ind Microbiol Biotechnol 33: 476-485.

SWARTZ, J.R. (2012). Transforming biochemical engineering with cell-free biology. AIChE J 58: 5-13.

SWARTZ, J.R., JEWETT, M.C. and WOODROW, K.A. (2004). Cell-free protein synthesis with prokaryotic combined transcription-translation. Methods Mol Biol267: 169-82.

THUNDIMADATHIL, J. (2012). Cancer treatment using peptides: current therapies and future prospects. J Amino Acids 967347.

TURCOTTE, R.F. and RAINES, R.T. (2008). Interaction of onconase with the human ribonuclease inhibitor protein. Biochem Biophys Res Commun 377: 512-514.

TYAGI, A., TUKNAIT, A., ANAND, P., GUPTA, S., SHARMA, M., MATHUR, D., JOSHI, A., SINGH, S., GAUTAM, A. and RAGHAVA, G.P. (2015). CancerPPD: a database of anticancer peptides and proteins. Nucleic Acids Res 43: D837-D840.

UNTCH, M., DITSCH, N. and HERMELINK, K. (2003). Immunotherapy: new options in breast cancer treatment. Expert Rev Anticancer Ther. 3: 403-408.

WANG, L., BROCK, A., HERBERICH, B. and SCHULTZ, P.G. (2001). Expanding the genetic code of Escherichia coli. Science 292: 498-500.

WELSH, J.P., BONOMO, J. and SWARTZ, J.R. (2011). Localization of BiP to translating ribosomes increases soluble accumulation of secreted eukaryotic proteins in an Escherichia coli cell-free system. Biotechnol Bioeng 108: 1739-1748.

WOODROW, K.A., AIREN, I.O. and SWARTZ, J.R. (2006). Rapid expression of functional genomic libraries. J Proteome Res 5: 3288-3300.

WOODROW, K.A. and SWARTZ, J.R. (2007). A sequential expression system for high-throughput functional genomic analysis. Proteomics 7: 3870-3879.

YABUKI, T., MOTODA, Y., HANADA, K., NUNOKAWA, E., SAITO, M., SEKI, E., INOUE, M., KIGAWA, T. and YOKOYAMA, S. (2007). A robust two-step PCR method of template DNA production for high-throughput cell-free protein synthesis. J Struct Funct Genomics 8: 173-191.

YAN, X. and XU, Z. (2006). Ribosome-display technology: applications for directed evolution of functional proteins. Drug Discov Today 11: 911-916.

YANG, H.-L., IVASHKIV, L., CHEN, H.-Z., ZUBAY, G. and CASHEL, M. (1980). Cell-free coupled transcription-translation system for investigation of linear DNA segments. Proc Natl Acad Sci U S A 77: 7029-7033.

YANG, J., KANTER, G., VOLOSHIN, A., MICHEL-REYDELLET, N., VELKEEN, H. LEVY, R. and SWARTZ, J.R. (2005). Rapid expression of vaccine proteins for B-cell lymphoma in a cell-free system. Biotechnol Bioeng 89: 503-511.

YOUNG, T.S., AHMAD, I., YIN, J.A. and SCHULTZ, P.G. (2010). An Enhanced System for Unnatural Amino Acid Mutagenesis in E. coli. J Mol Biol 395: 361-374.

ZÁRATE, X., HENDERSON, D.C., PHILLIPS, K.C., LAKE, A.D. and GALBRAITH, D.W. (2010). Development of high-yield autofluorescent protein microarrays using hybrid cell-free expression with combined Escherichia coli S30 and wheat germ extracts. Proteome Sci 8: 1-15.

ZAWADA, J.F., YIN, G., STEINER, A.R., YANG, J., NARESH, A., ROY, S.M., GOLD, D.S., HEINSOHN, H.G. and MURRAY, C.J. (2011). Microscale to manufacturing scale-up of cell-free cytokine production-a new approach for shortening protein production development timelines. Biotechnol Bioeng 108: 1570-1578.

ZIMMERMAN, E.S., HEIBECK, T.H., GILL, A., LI, X., MURRAY, C.J., MADLANSACAY, M.R., TRAN, C., UTER, N.T., YIN, G., RIVERS, P.J. et al., (2014). Production of Site-Specific Antibody-Drug Conjugates Using Optimized Non-Natural Amino Acids in a Cell-Free Expression System. Bioconjug Chem 25: 351-361. 


\section{Further Related Reading, published previously in the Int. J. Dev. Biol.}

Nuclear reprogramming in zygotes

Chanchao Lorthongpanich, Davor Solter and Chin Yan Lim

Int. J. Dev. Biol. (2010) 54: 1631-1640

http://dx.doi.org/10.1387/ijdb.103201cl

Faithful reprogramming to pluripotency in mammals - what does nuclear transfer teach us?

Julien Maruotti, Alice Jouneau and Jean-Paul Renard

Int. J. Dev. Biol. (2010) 54: 1609-1621

http://dx.doi.org/10.1387/ijdb.103195jm

Cyclin B2/cyclin-dependent kinase1 dissociation precedes CDK1 Thr-161 dephosphorylation upon M-phase promoting factor inactivation in Xenopus laevis cell-free extract

Franck Chesnel, Franck Bazile, Aude Pascal and Jacek Z. Kubiak

Int. J. Dev. Biol. (2007) 51: 297-305

http://dx.doi.org/10.1387/ijdb.072292fc

Remodeling of sperm chromatin induced in egg extracts of amphibians

C Katagiri and K Ohsumi

Int. J. Dev. Biol. (1994) 38: 209-216

http://dx.doi.org/10.1387/ijdb.7981030

The influence of mouse sera, regenerating liver extracts and bacterial products on the abilities of different cells in vitro N Zarkovic, M Osmak, D Novak, N Lers and M Jurin

Int. J. Dev. Biol. (1991) 35: 239-249

http://dx.doi.org/10.1387/ijdb.1814406
